\title{
Antiproliferative effects of anastrozole on MCF-7 human breast cancer cells in vitro are significantly enhanced by combined treatment with testosterone undecanoate
}

\author{
RONG CHEN, JUNWEI CUI, QINQIN WANG, PENG LI, XIAOLING LIU, HUI HU and WEI WEI \\ Department of Breast Surgery, Peking University Shenzhen Hospital, Shenzhen, Guangdong 518036, P.R. China
}

Received April 30, 2014; Accepted February 3, 2015

DOI: $10.3892 / \mathrm{mmr} .2015 .3427$

\begin{abstract}
The present study aimed to assess the effects of aromatase inhibitor anastrozole and testosterone undecanoate, separately and in combination, on proliferation and apoptosis in MCF-7 human breast cancer cells cultured in vitro. The effects of various concentrations of these drugs on the proliferation of MCF-7 cells were evaluated by CCK8 assay, the levels of cell apoptosis were evaluated by flow cytometry with Annexin-V/propidium iodide staining and androgen receptor (AR) protein expression was determined by western blot analysis. The results of the CCK8 assay indicated that greater antiproliferative activity was detected in the MCF-7 cells in the combined treatment groups, compared with those treated with anastrozole or testosterone undecanoate alone. Flow cytometric analysis of apoptosis revealed that treatment with a combination of the two drugs generated a higher percentage of apoptotic cells, particularly when the two drugs were applied for $48 \mathrm{~h}$, compared with single drug treatment. Western blot analysis revealed a significant decrease in AR protein expression in the combined treatment groups compared with MCF7 cells treated with single drugs. The results of the present study provided evidence supporting the potential of a combination of anastrozole and testosterone undecanoate as a novel therapeutic strategy for the treatment of breast cancer. Furthermore, it was demonstrated that the antiproliferative effects of anastrozole were significantly enhanced by combined treatment with testosterone undecanoate via the AR signaling pathway.
\end{abstract}

Correspondence to: Dr Wei Wei, Department of Breast Surgery, Peking University Shenzhen Hospital, 1120 Lianhua Road, Shenzhen, Guangdong 518036, P.R. China

E-mail: weiwei5117@hotmail.com

Abbreviations: HR, hormone receptor; AIs, aromatase inhibitors; ER, estrogen receptor; AR, androgen receptor; Dhea, dehydroepiandrosterone; TU, testosterone undecanoate; FBS, fetal bovine serum; DMSO, dimethyl sulfoxide; ATCC, American Type Culture Collection

Key words: breast cancer, anastrozole, testosterone undecanoate, androgen receptor

\section{Introduction}

Endocrine therapy has facilitated a significant survival advantage for patients with hormone receptor (HR)-positive breast cancer, with approximately two-thirds of patients with HR-positive breast cancer benefiting from endocrine therapies (1). Aromatase inhibitors (AIs), for example anastrozole, are currently considered to be the standard treatment for post-menopausal breast cancer patients with estrogen receptor (ER)-positive cancer subtypes, and they have been demonstrated to be more effective than the selective ER modulator tamoxifen (2). However, over the past several years, an increasing body of evidence has reported that drug resistance may still develop with anastrozole treatment (3-5). Treatment efficacy is limited through intrinsic and acquired therapeutic resistance (6). To date, studies have shown that $\sim 40 \%$ of primary resistance to endocrine therapy existed in ER-positive breast cancer and that almost all patients would lose sensitivity to endocrine drugs during the period of therapy (7). Macedo et al identified drug-resistance to anastrozole in vivo using mouse xenograft models of aromatase-overexpressing human ER1 breast cancer cells, which were in receipt of anastrozole treatment for several weeks. Resistant tumors exhibited high expression levels of insulin-like growth factor receptor $1 \mathrm{~b}$, mammalian target of rapamycin (mTOR) and phosphorylated-mTOR, as well as decreased expression of ERa and aromatase activity (8). The results of clinical trials conducted on patients with metastatic breast cancer additionally revealed that even tumors that initially respond to AI treatment later develop resistance, leading to disease progression and recurrence. These reasons indicate the requirement for the development of novel treatments for HR-positive breast cancer.

A previous study revealed that the AR is expressed in $60-70 \%$ of breast cancers, regardless of ER status (9). Hu et al observed that among 1467 cases of breast cancer, $78.7 \%$ were AR positive; and that among 1164 ER-positive cases of breast cancer, $88.0 \%$ were AR positive. AR positivity was associated with a significant reduction in breast cancer mortality and overall mortality (10). Previous studies have suggested that the majority (95\%) of ER-positive tumors are also AR positive (11-13). Amongst the ER-negative tumors, AR reactivity was observed in $10 \%$ of triple-negative cases [ER negative, progesterone receptor (PR) negative and human epidermal 
receptor 2 negative]. Certain studies have also demonstrated that dehydroepiandrosterone (Dhea) has growth inhibitory effects on ER- and PR-negative breast cancer cell lines with AR expression $(14,15)$. Morris et al reported that Dhea was compatible for the treatment of ER-negative and AR-positive breast cancer when combined with aromatase inhibitors (16).

Testosterone undecanoate, which is characterized by high safety and few side-effects, is the only existing oral form of testosterone replacement therapy, and is one of the most widely used androgens in clinical therapies (17-19). To the best of our knowledge, there are few reports evaluating the effects of androgen treatment for HR-positive breast cancer. The present study was therefore performed in order to evaluate the effects of combined treatment with testosterone undecanoate and anastrozole on HR-positive breast cancer cell proliferation, and to observe the mechanism of drug action.

\section{Materials and methods}

Main experimental materials. Testosterone undecanoate, Dulbecco's modified Eagle's medium (DMEM) and fetal bovine serum (FBS) were purchased from Sigma-Aldrich (St. Louis, MO, USA) and anastrozole tablets were bought from AstraZeneca (London, UK). Cell counting kit (CCK-8; WST-8, cat. no. C0038) was obtained from Dojindo Molecular Technologies, Inc. (Kumamoto, Japan). A cell apoptosis kit with Annexin-V (fluorescein isothiocyanate; FITC) and propidium iodide (PI) for flow cytometry was supplied by Life Technologies (Grand Island, NY, USA). AR (KGA21105), rabbit anti-human GAPDH monoclonal $(1: 1,000)$ and goat anti-rabbit secondary monoclonal $(1: 1,000)$ antibodies were purchased from Keygen Biotech Co. Ltd (Nanjing, China).

Drug preparation. The stock solutions of drugs were prepared in $0.1 \%$ dimethyl sulfoxide (DMSO) and stored at room temperature. The stock solutions of anastrozole and testosterone undecanoate were diluted in DMEM supplemented with 5\% FBS prior to use. The final stock solution of anastrozole was $1,000 \mu \mathrm{g} / \mathrm{ml}$ and in the in vitro studies, cells were treated with 0.1 or $0.01 \mu \mathrm{g} / \mathrm{ml}$. The trial concentrations of testosterone undecanoate used were 20 and $200 \mu \mathrm{g} / \mathrm{ml}$. The combinations of anastrozole and testosterone undecanoate used for the in vitro investigations were: $0.1 \mu \mathrm{g} / \mathrm{ml}$ anastrozole +20 or $200 \mu \mathrm{g} / \mathrm{ml}$ testosterone undecanoate and $0.01 \mu \mathrm{g} / \mathrm{ml}$ anastrozole +20 or $200 \mu \mathrm{g} / \mathrm{ml}$ testosterone undecanoate.

Cell culture. The MCF-7 [ER+, progesterone receptor (PR)+ and $\mathrm{AR+}$ ] breast cancer cells used were obtained from the American Type Culture Collection (ATCC; Manassas, VA, USA) and cultured according to the ATCC protocol. The MCF-7 ER+ line was grown in DMEM supplemented with $10 \%$ FBS and cultured in a $5 \% \mathrm{CO}_{2}$ enriched atmosphere at $37^{\circ} \mathrm{C}$. Images of the cells were captured using a BX51 microscope (Olympus, Tokyo, Japan). Briefly, 5x10 ${ }^{4}$ MCF7 cells were seeded into 6-well plates in $2 \mathrm{ml}$ DMEM, containing $10 \%$ FBS and $5 \times 10^{3}$ MCF7 cells were seeded into 96-well plates in $0.2 \mathrm{ml}$ DMEM, containing $10 \% \mathrm{FBS}$. The cells were cultured in a $5 \% \mathrm{CO}_{2}$ enriched atmosphere at $37^{\circ} \mathrm{C}$. The cell density was between 60 and $70 \%$ confluency on the day of the experiment and the old media was replaced. Following treatment with different drugs for 24, 48 and $72 \mathrm{~h}$, the cells in the 6-well plate were harvested for western blotting and flow cytometric analysis, and the cells in the 96-well plate were harvested for CCK-8 assessment.

Cell cytotoxicity assays. Cell cytotoxicity assays on MCF-7 cells following anastrozole and/or testosterone undecanoate treatment were performed using the CCK8 assay according to the manufacturer's instructions in 96-well plates. Exponentially growing cells were seeded at a density of 10,000 cells/well and allowed to grow for $24 \mathrm{~h}$. Following removal of the cell culture medium, MCF-7 cells were incubated for $0,24,48$ and $72 \mathrm{~h}$ in medium containing various concentrations of anastrozole and testosterone undecanoate. Subsequently, MCF-7 cells were treated with CCK8 reagent at $37^{\circ} \mathrm{C}$ for $1 \mathrm{~h}$ and the solution was converted to a quantifiable yellow dye by mitochondrial dehydrogenases present in viable cells. Absorbency was measured at $450 \mathrm{~nm}$ using a microplate reader (RT-6500; Rayto Life and Analytical Sciences Co., Ltd, Shenzhen, China).

Flow cytometric analysis. In order to elucidate the effects of the combination of anastrozole and testosterone undecanoate, MCF-7 cells were stained with Annexin-V and PI using an Annexin-V/PI staining kit according to the manufacturer's instructions to detect the level of apoptosis. MCF-7 cells were harvested through trypsinization and washed twice with cold phosphate-buffered saline. The cells were centrifuged at $1006.2 \mathrm{x} \mathrm{g}$ for $5 \mathrm{~min}$ and then the supernatant was discarded and the pellet was resuspended in $1 \mathrm{X}$ binding buffer at a density of $1.0 \times 10^{5}-1.0 \times 10^{6}$ cells $/ \mathrm{ml}$. Sample solution $(100 \mu \mathrm{l})$ was transferred to a $5 \mathrm{ml}$ culture tube and incubated with $5 \mu \mathrm{l}$ of FITC-conjugated annexin V (BD Biosciences, San Jose, CA, USA) and $5 \mu \mathrm{l}$ of PI (BD Biosciences) for $15 \mathrm{~min}$ at room temperature in the dark. Subsequently, $1 \mathrm{X}$ binding buffer (400 $\mu \mathrm{l}$ ) was added to each sample tube and the samples were analyzed using a flow cytometer (Gallios ${ }^{\mathrm{TM}}$; Beckman Coulter, Inc., Pasadena, CA, USA).

Western blot analysis. The four control groups comprised anastrozole-treated $(0.1$ and $0.01 \mu \mathrm{g} / \mathrm{ml})$ and testosterone undecanoate-treated (20 and $200 \mu \mathrm{g} / \mathrm{ml}$ ) cells, the two experimental groups were the combination-treated cells $(0.1 \mu \mathrm{g} / \mathrm{ml}+20 \mu \mathrm{g} / \mathrm{ml}$ and $0.1 \mu \mathrm{g} / \mathrm{ml}+200 \mu \mathrm{g} / \mathrm{ml})$. Cell lysates were prepared using modified radioimmunoprecipitation assay buffer (Keygen Biotech Co., Ltd) containing a tablet of complete protease inhibitors (Keygen Biotech Co., Ltd). The whole cell lysates were separated by $10 \%$ SDS-PAGE (Life Technologies) and the gels were transferred onto polyvinylidine difluoride membranes, blocked with 5\% skim milk powder (Life Technologies) and incubated with rabbit anti-human AR monoclonal antibody (1:1,000; cat. no. 21105; Keygen Biotech Co., Ltd., Nanjing, China). The band was visualized with enhanced chemiluminescent substrate (Life Technologies) following incubation at $4^{\circ} \mathrm{C}$ for $12 \mathrm{~h}$ with the appropriate horseradish peroxidase-conjugated secondary antibodies. Images were captured using an image analyzer (G:BOX chemiXR5; Synoptics Ltd, Cambridge, UK). 
Table I. A450 optical density values of MCF-7 cells following treatment with various drug concentrations at $0,24,48$ and $72 \mathrm{~h}$.

\begin{tabular}{lccrr}
\hline Treatment & $0 \mathrm{~h}$ & $24 \mathrm{~h}$ & $48 \mathrm{~h}$ & $72 \mathrm{~h}$ \\
\hline Anastrozole & & & & \\
$0.1 \mu \mathrm{g} / \mathrm{ml}$ & $0.7003 \pm 0.0524$ & $0.6766 \pm 0.0695$ & $1.2504 \pm 0.1943$ & $1.5202 \pm 0.0647$ \\
$0.01 \mu \mathrm{g} / \mathrm{ml}$ & $0.6810 \pm 0.0655$ & $0.6748 \pm 0.0725$ & $1.3049 \pm 0.0570$ & $1.4475 \pm 0.1843$ \\
$\mathrm{TU}$ & & & & \\
$20 \mu \mathrm{g} / \mathrm{ml}$ & $0.6818 \pm 0.7815$ & $0.6947 \pm 0.0481$ & $0.9674 \pm 0.1699$ & $1.2871 \pm 0.1876$ \\
$200 \mu \mathrm{g} / \mathrm{ml}$ & $0.6743 \pm 0.0266$ & $0.5756 \pm 0.0361$ & $0.7052 \pm 0.0860$ & $0.1244 \pm 0.0132$ \\
$\mathrm{Combined} \mathrm{(anastrozole}+\mathrm{TU})$ & & & & \\
$0.1 \mu \mathrm{g} / \mathrm{ml}+20 \mu \mathrm{g} / \mathrm{ml}$ & $0.6445 \pm 0.0517$ & $0.6621 \pm 0.0592$ & $1.0259 \pm 0.0608$ & $0.9764 \pm 0.1031$ \\
$0.1 \mu \mathrm{g} / \mathrm{ml}+200 \mu \mathrm{g} / \mathrm{ml}$ & $0.6765 \pm 0.0321$ & $0.3345 \pm 0.0248$ & $0.1525 \pm 0.0238$ & $0.1221 \pm 0.0039$ \\
$0.01 \mu \mathrm{g} / \mathrm{ml}+20 \mu \mathrm{g} / \mathrm{ml}$ & $0.6986 \pm 0.0633$ & $0.6548 \pm 0.0886$ & $1.1009 \pm 0.1167$ & $1.1073 \pm 0.1394$ \\
$0.01 \mu \mathrm{g} / \mathrm{ml}+200 \mu \mathrm{g} / \mathrm{ml}$ & $0.6639 \pm 0.4530$ & $0.3591 \pm 0.0454$ & $0.1726 \pm 0.0525$ & $0.1485 \pm 0.0330$ \\
Control group & $0.6989 \pm 0.0361$ & $0.7390 \pm 0.0535$ & $1.4018 \pm 0.1182$ & $1.6516 \pm 0.1107$
\end{tabular}

TU, testosterone undecanoate.

A

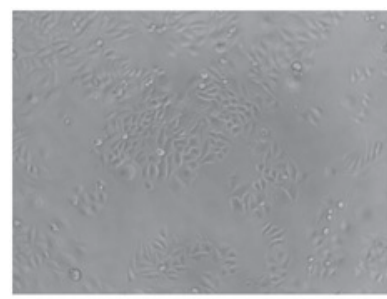

E

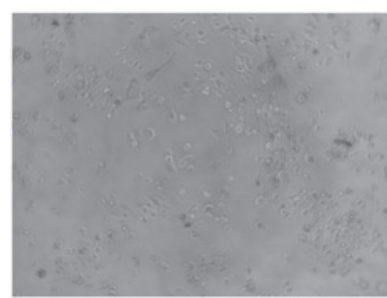

I

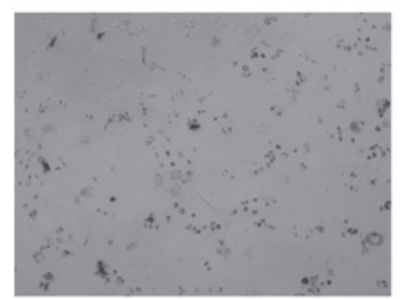

$\mathbf{B}$

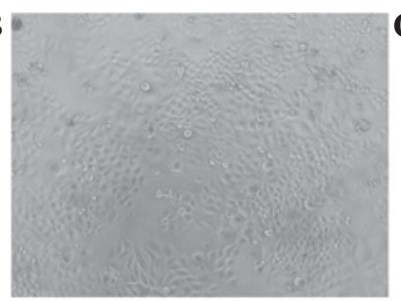

$\mathbf{F}$

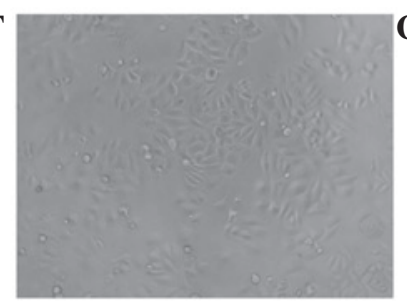

J

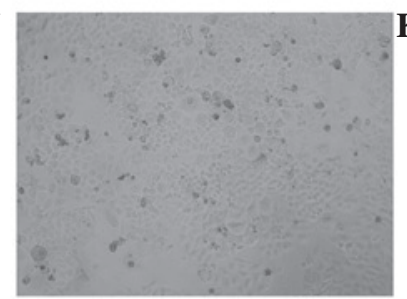

C

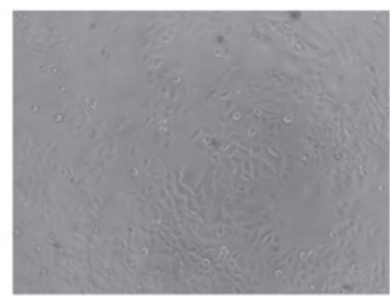

G
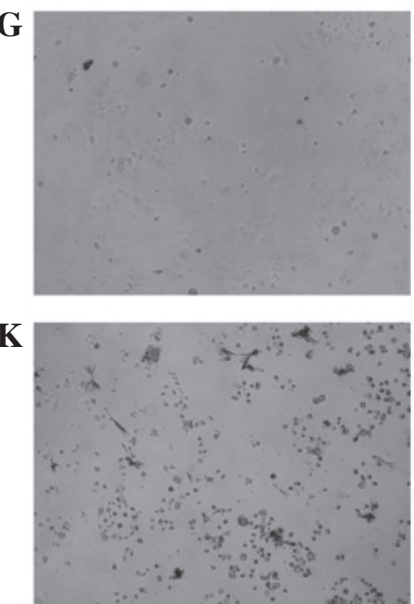

D

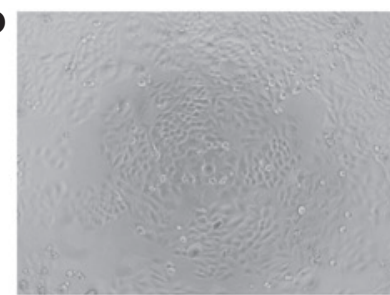

H

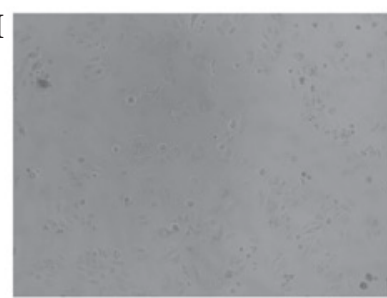

L

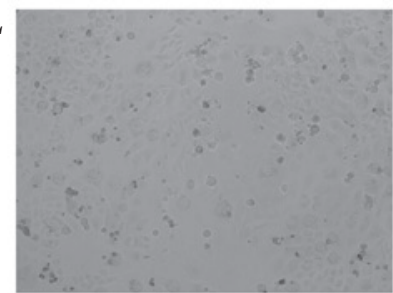

Figure 1. MCF-7 human breast cancer cells were cultured with and without various concentrations of the test compounds (magnification, $\mathrm{x} 100)$. (A and B) Normal MCF-7 cells cultured for 24 and $72 \mathrm{~h}$, respectively; (C and D) cells cultured with diluted concentration dimethyl sulfoxide for 24 and $72 \mathrm{~h}$, respectively; (E and F) cells cultured with $0.1 \mu \mathrm{g} / \mathrm{ml}$ anastrozole for 24 and $72 \mathrm{~h}$, respectively; $(\mathrm{G}$ and $\mathrm{H}$ ) cells cultured with $0.01 \mu \mathrm{g} / \mathrm{ml}$ anastrozole for 24 and $72 \mathrm{~h}$, respectively; (I and J) cells cultured with $0.1 \mu \mathrm{g} / \mathrm{ml}$ anastrozole plus $200 \mu \mathrm{g} / \mathrm{ml}$ testosterone undecanoate for 24 and $72 \mathrm{~h}$, respectively and (K and L) cells cultured with $0.1 \mu \mathrm{g} / \mathrm{ml}$ anastrozole plus $20 \mu \mathrm{g} / \mathrm{ml}$ testosterone undecanoate for 24 and $72 \mathrm{~h}$, respectively.

Statistical analysis. The results are presented as the mean \pm standard deviation. Statistical analysis was performed using SPSS 13.0 software (SPSS, Inc., Chicago, IL, USA). The results of the cell cytotoxicity and western blot assays were analyzed by one-way analysis of variance to compare data from cell cultures treated with various drug concentrations and incubation times of anastrozole and testosterone undecanoate. $\mathrm{P}<0.05$ was considered to indicate a statistically significant difference between values.

\section{Results}

Combined treatment with anastrozole and testosterone undecanoate enhances cytotoxity in MCF-7 cells. A cytotoxity assay was performed in order to analyze MCF-7 cell viability following treatments with anastrozole and/or testosterone undecanoate for $0,24,48$ and $72 \mathrm{~h}$. The main cytotoxicities of the drugs included reducing the number of MCF-7 cells and inducing cell lysis (Fig. 1). A microplate reader was 


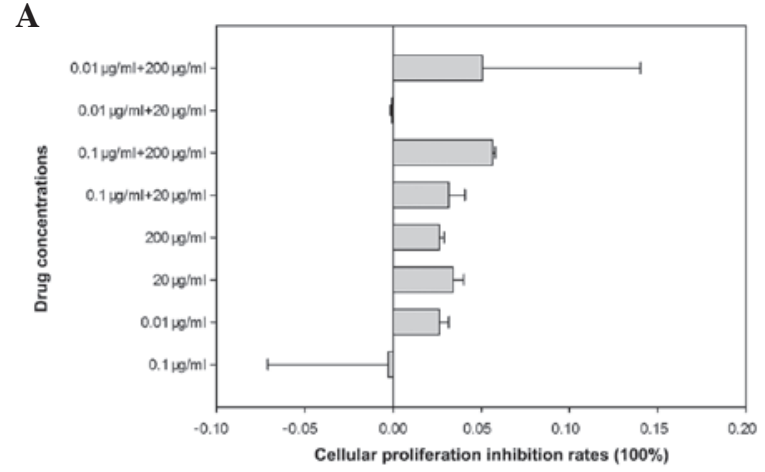

B

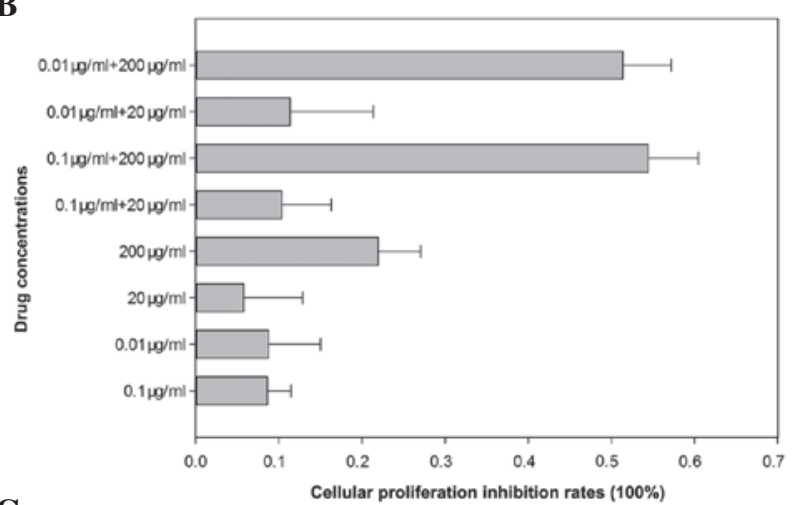

C

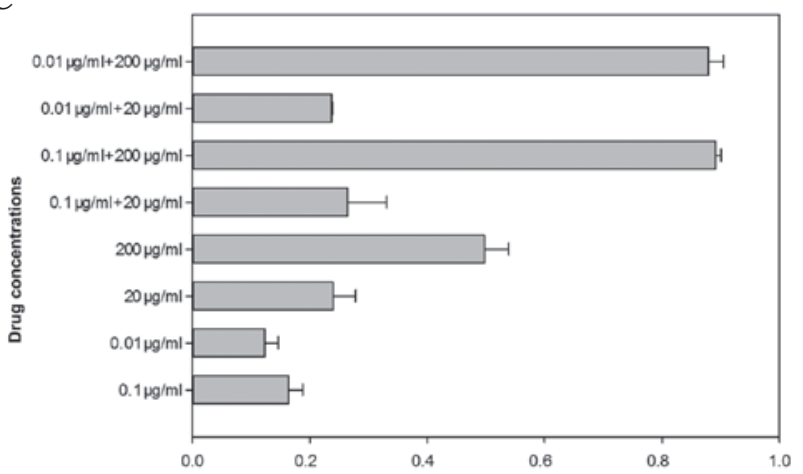

D

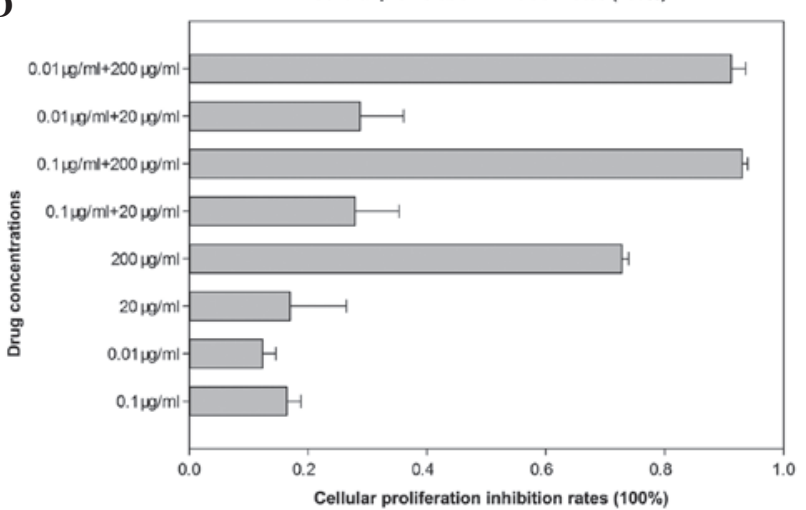

Figure 2. Cellular proliferation inhibition rates following treatment with various drug concentrations for (A) $0 \mathrm{~h},(B) 24 \mathrm{~h}$, (C) $48 \mathrm{~h}$ and (D) $72 \mathrm{~h}$. Values are expressed as the mean \pm standard deviation. All drug combination groups exhibited significantly fewer viable cells than those of the anastrozole-treated groups $(\mathrm{P}<0.05)$ at 24,48 and $72 \mathrm{~h}$.

subsequently used to measure the absorbency of the solution in each well (Table 1). The cellular proliferation inhibition rates following different drugs within 0-24 h were low and no significant differences among different groups were identified
A

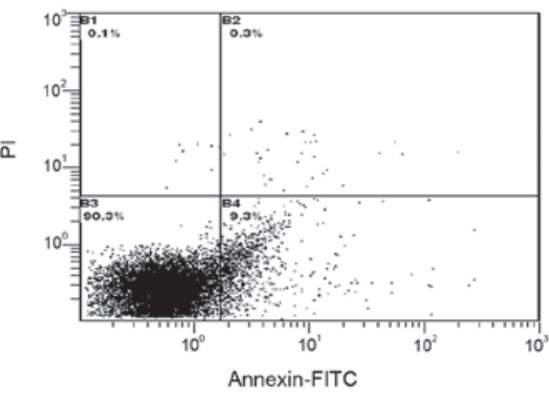

B

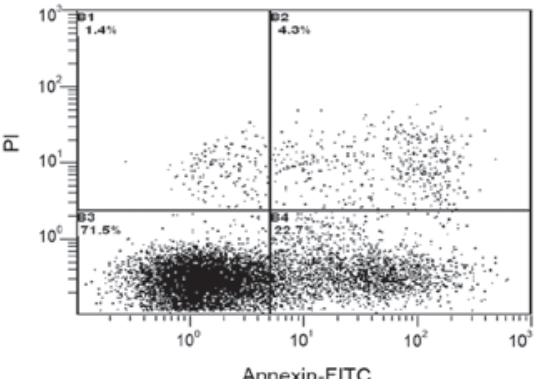

C

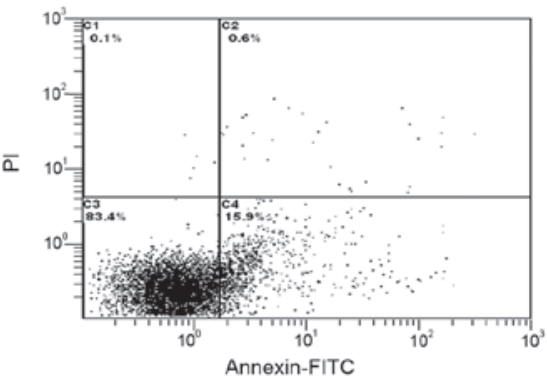

D

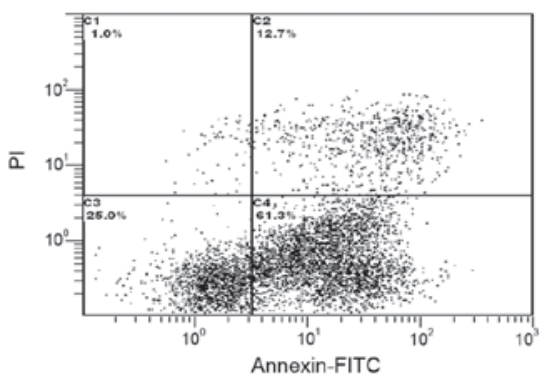

$\mathbf{E}$

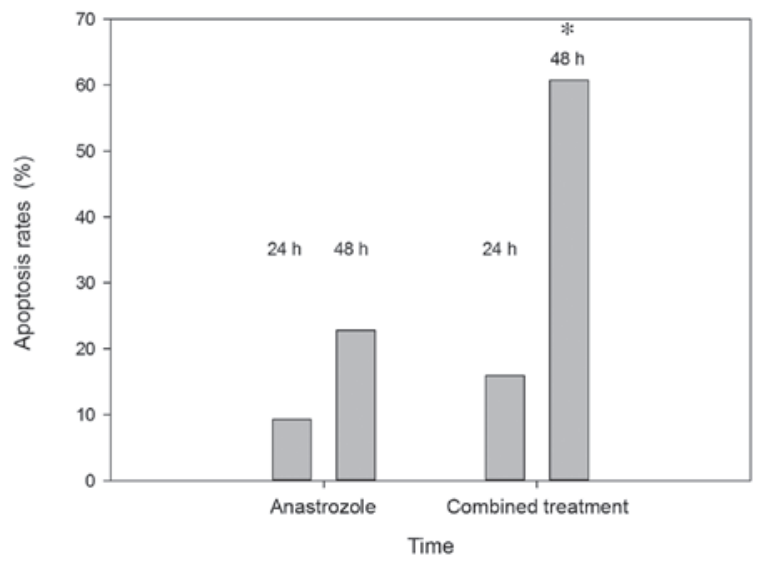

Figure 3. Flow cytometric analysis of apoptosis in MCF-7 cells (A) Anastrozole-treated group following $24 \mathrm{~h}$ of treatment, (B) anastrozole-treated group following $48 \mathrm{~h}$ of treatment, (C) combined treatment group following $24 \mathrm{~h}$ of treatment and (D) combined treatment group following $48 \mathrm{~h}$ of treatment. (E) Quantification of levels of apoptosis in the two groups at 24 and $48 \mathrm{~h}$. The average percentage of apoptotic cells was significantly higher ( $60.73 \pm 0.81$ vs. $22.73 \pm 0.35 \%,{ }^{*} \mathrm{P}<0.05$, compared with the anastrozole treatment alone followin $48 \mathrm{~h}$ ) at $48 \mathrm{~h}$ in MCF-7 cells treated with a combination of drugs, compared with those treated with anastrozole alone. PI, propidium iodide; FITC, fluorescein isothiocyanate. 
A

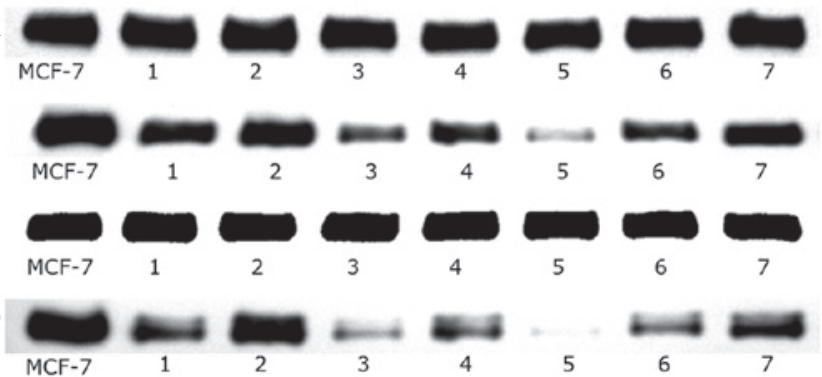

Figure 4. Evaluation of GAPDH and AR protein expression by western blo analysis. (A) GAPDH and (B-D) AR. Lanes: $1,0.1 \mu \mathrm{g} / \mathrm{ml}$ anastrozole; 2, $0.01 \mu \mathrm{g} / \mathrm{ml}$ anastrozole; $3,200 \mu \mathrm{g} / \mathrm{ml}$ testosterone undecanoate; $4,20 \mu \mathrm{g} / \mathrm{ml}$ testosterone undecanoate; $5,0.1 \mu \mathrm{g} / \mathrm{ml}$ anastrozole $+200 \mu \mathrm{g} / \mathrm{ml}$ testosterone undecanoate; $6,0.1 \mu \mathrm{g} / \mathrm{ml}$ anastrozole $+20 \mu \mathrm{g} / \mathrm{ml}$ testosterone undecanoate; 7 , dimethyl sulfoxide group. AR, androgen receptor.

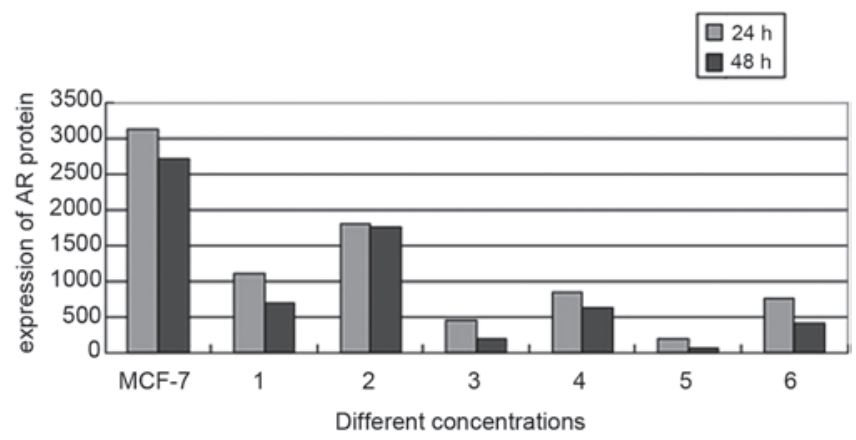

Figure 5. Quantification of AR protein expression levels following drug treatment for 24 and $48 \mathrm{~h} .1,0.1 \mu \mathrm{g} / \mathrm{ml}$ anastrozole; $2,0.01 \mu \mathrm{g} / \mathrm{ml}$ anastrozole; 3 , $200 \mu \mathrm{g} / \mathrm{ml}$ testosterone undecanoate; $4,20 \mu \mathrm{g} / \mathrm{ml}$ testosterone undecanoate $5,0.1 \mu \mathrm{g} / \mathrm{ml}$ anastrozole $+200 \mu \mathrm{g} / \mathrm{ml}$ testosterone undecanoate; $6,0.1 \mu \mathrm{g} / \mathrm{ml}$ anastrozole $+20 \mu \mathrm{g} / \mathrm{ml}$ testosterone undecanoate. AR, androgen receptor.

(Fig. 2A). As indicated in Fig. 2, the results revealed that compared with anastrozole-treated $(0.1$ or $0.01 \mu \mathrm{g} / \mathrm{ml})$ cells, the cellular proliferation inhibition rates of combination-treated $(0.1 \mu \mathrm{g} / \mathrm{ml}+200 \mu \mathrm{g} / \mathrm{ml}$ or $0.01 \mu \mathrm{g} / \mathrm{ml}+200 \mu \mathrm{g} / \mathrm{ml})$ cells were significantly higher following $24 \mathrm{~h}$ of treatment $(\mathrm{P}<0.05$; Fig. 2B). However, there was no significant decrease in MCF-7 cell viability among other concentration combinations $(0.1 \mu \mathrm{g} / \mathrm{ml}+20 \mu \mathrm{g} / \mathrm{ml}$ and $0.01 \mu \mathrm{g} / \mathrm{ml}+20 \mu \mathrm{g} / \mathrm{ml} ; \mathrm{P}>0.05)$. Following $48 \mathrm{~h}$ of treatment, the testosterone undecanoate and all drug combination groups had significantly fewer viable cells than those of the anastrozole-treated group $(\mathrm{P}<0.05$; Fig. 2C). Following treating for $72 \mathrm{~h}$, the cellular proliferation inhibition rates in all groups were higher than at $0-24 \mathrm{~h}$ and the results revealed that the drug combination groups eradicated more cancer cells than the anastrozole-treated group (Fig. 2D).

Combined treatment enhances apoptosis in MCF-7 cells. Fig. 3 exhibits representative flow cytometric scatter plots of MCF-7 cells double-stained with Annexin V-FITC and PI, revealing the number of apoptotic cells 24 and $48 \mathrm{~h}$ following treatment with anastrozole $(0.1 \mu \mathrm{g} / \mathrm{ml}$; Fig. $3 \mathrm{~A}$ and B) and combined drug treatment $(0.1 \mu \mathrm{g} / \mathrm{ml}$ anastrozole $+20 \mu \mathrm{g} / \mathrm{ml}$ testosterone undecanoate; Fig. 3C and D). There were significant differences in the level of apoptosis between the various concentrations of drugs at 24 and $48 \mathrm{~h}$. Data analysis revealed that the average percentage of apoptotic cells was significantly higher at $48 \mathrm{~h}$ in MCF-7 cells treated with the drug combination, compared with anastrozole treatment alone $(60.73 \pm 0.81 \%$ vs. $22.73 \pm 0.35 \%$; $\mathrm{P}<0.05$; Fig. 3E).

$A R$ protein expression is decreased in the combined treatment groups. To elucidate whether the AR signaling pathway functioned via direct interaction with the combined treatment drug pathway, the expression of AR protein in MCF-7 cells was evaluated via western blot analysis in the various concentration treatment groups following 24 and $48 \mathrm{~h}$ of incubation. A significant decrease in AR protein expression was observed in the $0.1 \mu \mathrm{g} / \mathrm{ml}+20 \mu \mathrm{g} / \mathrm{ml}$ and $0.1 \mu \mathrm{g} / \mathrm{ml}+200 \mu \mathrm{g} / \mathrm{ml}$ co-treated MCF-7 cells, compared with that of the untreated cells (Fig. 4). Quantification of the bands indicated that the AR protein expression levels were significantly reduced in the $0.1 \mu \mathrm{g} / \mathrm{ml}+20 \mu \mathrm{g} / \mathrm{ml}$ combined treatment group, compared with those of the $20 \mu \mathrm{g} / \mathrm{ml}$ testosterone undecanoate-treated group ( $755.88 \pm 0.95$ vs. $854.51 \pm 2.17 ; \mathrm{P}<0.05)$. In addition, the AR expression levels in the $0.1 \mu \mathrm{g} / \mathrm{ml}+200 \mu \mathrm{g} / \mathrm{ml}$ experimental group were significantly lower than those is the $200 \mu \mathrm{g} / \mathrm{ml}$ testosterone undecanoate-treated group $(194.35 \pm 1.01$ vs. $453.74 \pm 2.07$; $\mathrm{P}<0.05$; Fig. 5).

\section{Discussion}

Breast cancer is one of the most common types of cancer observed among females. Endocrine therapies targeting hormone receptors or aromatase have successfully improved the overall survival and markedly reduced the risk of recurrence of patients with ER positive breast cancer. Despite such developments, certain patients with ER-positive or -negative types of breast cancer still lose sensitivity to endocrine therapy, reducing its effectiveness. The mechanisms underlying this effect have remained to be elucidated. To date, studies have revealed that the androgen signaling pathway may have key functions in normal and malignant breast tissue (20). ARs are the most ubiquitously expressed sex-steroid receptors amongst malignant breast tumors, and are expressed in up to $90 \%$ of primary tumors and $75 \%$ of metastases (21). Previous studies have indicated that AR expression is positively correlated with ER $\alpha$ and PR expression, as well as low proliferative activity (22-24). Prostate cancer and breast cancer share similar biological features and common components (25). Previous studies have suggested that AR may contribute to prostate cancer growth during its recurrence and that endocrine therapy targeting AR may delay prostate cancer progression by inhibiting AR activity via androgen ablation and regulation of signal transduction pathways (26). As a result, AR dysregulation and its potential therapeutic value have been investigated in this group of breast neoplasms (27). Ni et al demonstrated that AR functioned as an antiproliferative effector in ER-positive breast cancer, but that it facilitated tumor cell growth in AR-positive and ER-negative cell line models of breast cancer in an androgen-dependent manner (28). A retrospective study, which followed 508 postmenopausal females in South Australia receiving testosterone treatment in addition to normal hormone therapy, hypothesized that the inclusion of testosterone with conventional hormone therapy for postmenopausal females did not increase, and may reduce, the risk of hormone therapy-associated breast 
cancer; therefore, returning the levels of incidence to those observed in the general untreated population (29). The results of the present study revealed when MCF-7 ER-positive breast cancer cells were co-treated with anastrozole and testosterone undecanoate, the anti-proliferative effects were enhanced and the levels of apoptosis were more than two-fold greater in cells treated with anastrozole and various concentrations of testosterone undecanoate, compared with those of cells receiving anastrozole treatment alone.

Notably, it was also demonstrated that the AR signaling pathway was suppressed and the AR protein level was significantly reduced following anastrozole and testosterone undecanoate combined treatment, compared with the two drugs alone, respectively. Previous studies have evaluated the association between AR expression in breast cancer and the effectiveness of hormone therapies, including tamoxifen and AI treatments, using ER-positive breast cancer cell lines. The results indicated that AR overexpression may induce tamoxifen resistance (30-32); and therefore, if AR expression influences the activity of tamoxifen (33), then tamoxifen should only be used in the treatment of AR-negative subtypes of breast cancer (13). Further studies have also demonstrated that the cytotoxic effects of anastrozole on breast cancer cells could be enhanced by treating with androgens simultaneously (34-36). However, based on the results of the present study, various concentrations of testosterone undecanoate were utilized to reduce the expression of AR protein, as previously reported (37), and therefore significantly enhance the cytotoxic effects of anastrozole. Further studies are required to evaluate these hypotheses and confirm the present findings.

In conclusion, the antiproliferative effects of anastrozole on MCF-7 human breast cancer cells were significantly enhanced by combined treatment with testosterone undecanoate, and the AR signaling pathway may represent a novel target for the development of breast cancer therapies.

\section{Acknowledgements}

The research described in the present study was supported by the Shenzhen Science and Research Innovation Foundation (no. JCYJ20130402114702122) and the Shenzhen Science and Technology Plan Projects (no. 201103010). The authors would like to thank the Pharmacy Department and Central Laboratory of Peking University Shenzhen Hospital (Shenzhen, China) for their technical support.

\section{References}

1. Burstein HJ, Prestrud AA, Seidenfeld J, et al; American Society of Clinical Oncology: American Society of Clinical Oncology clinical practice guideline: update on adjuvant endocrine therapy for women with hormone receptor-positive breast cancer. J Clin Oncol 28: 3784-3796, 2010.

2. Geisler J, King N, Anker G, et al: In vivo inhibition of aromatization by exemestane, a novel irreversible aromatase inhibitor, in postmenopausal breast cancer patients. Clin Cancer Res 4: 2089-2093, 1998.

3. Wong ST and Goodin S: Overcoming drug resistance in patients with metastatic breast cancer. Pharmacotherapy 29: 954-965, 2009.

4. Moy I, Lin Z, Rademaker AW, Reierstad S, Khan SA and Bulun SE: Expression of estrogen-related gene markers in breast cancer tissue predicts aromatase inhibitor responsiveness. PLoS One 8: e77543, 2013.
5. Madeira M, Mattar A, Logullo AF, Soares FA and Gebrim LH: Estrogen receptor alpha/beta ratio and estrogen receptor beta as predictors of endocrine therapy responsiveness-a randomized neoadjuvant trial comparison between anastrozole and tamoxifen for the treatment of postmenopausal breast cancer. BMC Cancer 13: 425, 2013.

6. Lønning PE and Eikesdal HP: Aromatase inhibition 2013: clinical state of the art and questions that remain to be solved. Endocr Relat Cancer 20: R183-R201, 2013.

7. Normanno N, Di Maio M, De Maio E, et al: Mechanisms of endocrine resistance and novel therapeutic strategies in breast cancer. Endocr Relat Cancer 12: 721-747, 2005.

8. Macedo LF, Sabnis GJ, Goloubeva OG and Brodie A: Combination of anastrozole with fulvestrant in the intratumoral aromatase xenograft model. Cancer Res 68: 3516-3522, 2008.

9. Castellano I, Allia E, Accortanzo V, et al: Androgen receptor expression is a significant prognostic factor in estrogen receptor positive breast cancers. Breast Cancer Res Treat 124: 607-617, 2010.

10. Hu R, Dawood S, Holmes MD, et al: Androgen receptor expression and breast cancer survival in postmenopausal women. Clin Cancer Res 17: 1867-1874, 2011.

11. Agoff SN, Swanson PE, Linden H, Hawes SE and Lawton TJ: Androgen receptor expression in estrogen receptor-negative breast cancer. Immunohistochemical, clinical, and prognostic associations. Am J Clin Pathol 120: 725-731, 2003.

12. Moinfar F, Okcu M, Tsybrovskyy O, et al: Androgen receptors frequently are expressed in breast carcinomas: potential relevance to new therapeutic strategies. Cancer 98: 703-711, 2003.

13. Niemeier LA, Dabbs DJ, Beriwal S, Striebel JM and Bhargava R: Androgen receptor in breast cancer: expression in estrogen receptor-positive tumors and in estrogen receptor-negative tumors with apocrine differentiation. Mod Pathol 23: 205-212, 2010.

14. Somboonporn W and Davis SR; National Health and Medical Research Council: Testosterone effects on the breast: implications for testosterone therapy for women. Endocr Rev 25: 374-388, 2004.

15. Nahleh Z: Androgen receptor as a target for the treatment of hormone receptor-negative breast cancer: an unchartered territory. Future Oncol 4: 15-21, 2008.

16. Morris KT, Toth-Fejel S, Schmidt J, Fletcher WS and Pommier RF: High dehydroepiandrosterone-sulfate predicts breast cancer progression during new aromatase inhibitor therapy and stimulates breast cancer cell growth in tissue culture: a renewed role for adrenalectomy. Surgery 130: 947-953, 2001.

17. Gooren LJ: A ten-year safety study of the oral androgen testosterone undecanoate. J Androl 15: 212-215, 1994.

18. Schubert M, Minnemann T, Hübler D, et al: Intramuscular testosterone undecanoate: pharmacokinetic aspects of a novel testosterone formulation during long-term treatment of men with hypogonadism. J Clin Endocrinol Metab 89: 5429-5434, 2004.

19. Saad F, Haider A and Gooren L: Effects of long-term treatment of hypogonadal men with testosterone undecanoate on blood pressure, fasting glucose, $\mathrm{HbA1c}$ and $\mathrm{C}$-reactive protein. Endocrine Abstracts 29: 315, 2012.

20. Peters AA, Buchanan G, Ricciardelli C, et al: Androgen receptor inhibits estrogen receptor-alpha activity and is prognostic in breast cancer. Cancer Res 69: 6131-6140, 2009.

21. Gonzalez LO, Corte MD, Vazquez J, et al: Androgen receptor expresion in breast cancer: relationship with clinicopathological characteristics of the tumors, prognosis and expression of metalloproteases and their inhibitors. BMC Cancer 8: 149, 2008.

22. Labrie F, Simard J, de Launoit Y, et al: Androgens and breast cancer. Cancer Detect Prev 16: 31-38, 1992.

23. Weigelt B, Mackay A, A'hern R, et al: Breast cancer molecular profiling with single sample predictors: a retrospective analysis. Lancet Oncol 11: 339-349, 2010.

24. Hugh J, Hanson J, Cheang MC, et al: Breast cancer subtypes and response to docetaxel in node-positive breast cancer: use of an immunohistochemical definition in the BCIRG 001 trial. J Clin Oncol 27: 1168-1176, 2009.

25. Robinson JL, MacArthur S, Ross-Innes CS, et al: Androgen receptor driven transcription in molecular apocrine breast cancer is mediated by FoxA1. EMBO J 30: 3019-3027, 2011.

26. Wang $\mathrm{Q}, \mathrm{Li} \mathrm{W}$, Zhang $\mathrm{Y}$, et al: Androgen receptor regulates a distinct transcription program in androgen-independent prostate cancer. Cell 138: 245-256, 2009.

27. Hu R, Dawood S, Holmes MD, et al: Androgen receptor expression and breast cancer survival in postmenopausal women. Clin Cancer Res 17: 1867-1874, 2011. 
28. Ni M, Chen Y, Lim E, et al: Targeting androgen receptor in estrogen receptor-negative breast cancer. Cancer Cell 20: 119-131, 2011

29. Dimitrakakis C, Jones RA, Liu A and Bondy CA: Breast cancer incidence in postmenopausal women using testosterone in addition to usual hormone therapy. Menopause 11: 531-535, 2004.

30. Santoni G and Farfariello V: TRP channels and cancer: new targets for diagnosis and chemotherapy. Endocr Metab Immune Disord Drug Targets 11: 54-67, 2011.

31. Kuenen-Boumeester V, Van der Kwast TH, van Putten W, Claassen C, VanOoijen B and Henzen-Logmans SC: Immunohistochemical determination of androgen receptors in relation to oestrogen and progesterone receptors in female breast cancer. Int J Cancer 52: 581-584, 1992.

32. Hickey TE, Robinson JL, Carroll JS and Tilley WD: Minireview: The androgen receptor in breast tissues: growth inhibitor, tumorsuppressor, oncogene? Mol Endocrinol 26: 1252-1267, 2012.
33. Tokunaga E, Hisamatsu Y, Taketani K, et al: Differential impact of the expression of the androgen receptor by age in estrogen receptor-positive breast cancer. Cancer Med 2: 763-773, 2013.

34. Doane AS, Danso M, Lal P, Donaton M, Zhang L, Hudis C and Gerald WL: An estrogen receptor-negative breast cancer subset characterized by a hormonally regulated transcriptional program and response to androgen. Oncogene 25: 3994-4008, 2006.

35. Yu Q, Niu Y, Liu N, et al: Expression of androgen receptor in breast cancer and its significance as a prognostic factor. Ann Oncol 22: 1288-1294, 2011.

36. Campagnoli C, Pasanisi P, Castellano I, Abba C, Brucato T and Berrino F: Postmenopausal breast cancer, androgens, and aromatase inhibitors. Breast Cancer Res Treat 139: 1-11, 2013.

37. Liu CQ, Wu SZ, Wang ZD, Lai WY and Sun F: Effect of testosterone on expression of androgen receptor in human monocytic cell line THP-1. Di Yi Jun Yi Da Xue Xue Bao 24: 389-391, 2004 (In Chinese). 